\title{
NOTES
}

\section{"PASSAGE TO INDIA": WHITMAN AND LUCRETIUS}

Shortly after the opening of his "Passage to India," Whitman launches a description of the infinity of time, a description notable for its vivid spatial imagery: "The Past - the dark unfathom'd retrospect! / The teeming gulf-the sleepers and the shadows! / The past-the infinite greatness of the past! / For what is the present after all but a growth out of the past?" (10-13)

Whitman then introduces a curious parenthesis: "As a projectile form'd, impell'd, passing a certain line, still keeps on, / So the present, utterly form'd, impell'd by the past" (14-15). A puzzling statement, indeed. A simile that would appear to defeat rather than enhance the point. Time is the eternal passage from past into present. It proceeds uninterruptedly like a projectile that is hurled and "still keeps on." But what projectile "still keeps on"? What thrown object can be analogous to the infinite passage of time?

The answer lies in the reader's recognition of Whitman's allusion here. In another famous text dealing with infinity-the infinity of matter and voidLucretius represents a man at the edge of the world hurling a missile into the void, in which - if indeed the void, like matter, is infinite-it will go hurtling on forever: "If a man ran forward to the farthest edge < of the world> and cast a flying missile ... it would go whither it had been sent and fly on afar . . . it proceeds far off" (De Rerum Natura 1:969-979). Whitman's reader will recognize that Lucretius's projectile, thrown into the infinite void, will go on forever and so is a perfect analogy for Whitman's course of infinite time that itself "still keeps on." In a poem of cosmic purport, it is no surprise to hear Whitman echoing Lucretius, antiquity's greatest poet of the cosmos, and one highly regarded by Whitman, who speaks of "all the great imported art-works, treatises, systems, from Lucretius down."

Indeed, the relationship of "Passage" to Lucretius's great poem is probably more extensive and deeper than this single allusion. In a very real and powerful sense, "Passage" falls into the tradition of works that are Lucretian in style and substance, yet fundamentally "Anti-Lucretius." ${ }^{3}$ Early on Whitman writes, "Eclaircise the myths Asiatic, the primitive fables" (17). Lucretius of course is the paradigmatic opponent of fables and myths. Whitman continues, "Not you alone proud truths of the world, / Nor you alone ye facts of modern science, / But myths and fables of eld, Asia's, Africa's fables, / The far-darting beams of the spirit, the unloos'd dreams, / The deep diving bibles and legends, / The daring plots of the poets, the elder religions" (18-23). This sentiment is diametrically opposed to Lucretius's view that reason, truth, and science will in fact drive out the base coin of fables, dreams, legends, and religion. The very language ("the unloos'd dreams . . . the daring plots of the poets, the elder religions") will make us recall Lucretius's tirade at the opening of his treatise, tantum religio potuit suadere malorum. / . . vatum / terriloquis 
... dictis . . / multa . . somnia . . . / religionibus atque minis . . vatum (1:101109). The mention of "temples fairer than lilies" and "fables mounting to heaven" (23-24) counters Lucretius's scorn of both temples (e.g. 5:74-75, 6:417-418, 6:1272-1273) and fables. In all progress, Whitman can see "God's purpose from the first" (31). Lucretius knows that quaeque fiant opera sine divom, that all things come about without the role of deity (1:158).

Lucretius believes that all can be discovered and explained by the application of human reason (e.g. 1:143-148). But in the workings of the world Whitman sees an "inscrutable purpose, some hidden prophetic intention" (86). Whitman's words here seem a response to a passage in Lucretius: "Alternate light and day and the teeming spiritual darkness, / Unspeakable high processions of sun and moon and countless stars above, / . . With inscrutable purpose, some hidden prophetic intention, / Now first it seems my thought begins to span thee" (83-87). Lucretius had written of the ordered procession of the heavens, the sun, the moon, the stars, the ordered alternation of day and night and the seasons, and saw man's inability to explain the natural order as the source of human anxiety and unhappiness (5:1183-1193). But for Whitman this is indeed the beginning of wisdom.

One can sense in Whitman's remarks about Lucretius and a contra-Lucretius in his Democratic Vistas a presentiment of what he himself would do in "Passage," namely to take root from Lucretius but produce a very different plant: "What the Roman Lucretius sought most nobly, yet all too blindly, negatively to do for his age and its successors, must be done positively by some great coming literatus, especially poet, who, while remaining fully poet, will absorb whatever science indicates, with spiritualism, and out of them, and out of his own genius, will compose the great poem of death. Then will man indeed confront Nature, and confront time and space, both with science, and con amore, and take his right place, prepared for life, master of fortune and misfortune. And then that which was long wanted will be supplied, and the ship that had it not before in all her voyages, will have an anchor" (PW 2:421).

Knowledge, Lucretius felt, would lead a man away from belief in religion. The view of "Passage," in the words of S. K. Coffman, Jr., is that "knowledge leads inevitably to faith." 4 There we have it: Lucretius and Anti-Lucretius, Whitman no less than Cardinal Polignac. ${ }^{5}$

University of Illinois, Urbana

HOWARD JACOBSON

\section{NOTES}

1 Whitman's “passing a certain line" probably reflects Lucretius's reference to repeated hypothetical "ends" of the universe (1:969-970, 980-981).

2 Prose Works 1892, ed. Floyd Stovall (New York: New York University Press, 1964), 2:485. Hereafter cited parenthetically as $P W$. Some believe that Leaves of Grass was broadly influenced by Lucretius. For example, see Frederik Schyberg, Walt Whitman (New York: Columbia University Press, 1951), 253.

3 For example, the works of Scipione Capece and Aonio Paleario (both sixteenth century) and, most notably, that of Cardinal Polignac (eighteenth century). 
4 S. K. Coffman, Jr., "Form and Meaning in Whitman's 'Passage to India'" $P M L A$ 70 (1955), 338.

5 There are, I suspect, other instances of Lucretian "presence" in "Passage." Thus, the repeated invocations of the soul must be counterpoint to Lucretius's emphatic notion of the soul as just another collection of atoms. The description of the earth as "swimming in space" (81) may owe something to Lucretius's description of the earth as "hanging in space" (in spatio pendere: 2:602-603). The "voiceless earth" (110) is Lucretius's "silent" mother-earth (2:625: muta). The metaphorical description of "the true son of God, the poet, / (He shall indeed pass the straits and conquer the mountains" (111-112) recalls Lucretius's portrait of his nearly deified hero, Epicurus, who is metaphorically both traveller and conqueror (1:72-74). 